\title{
Inheritance and Heritability of Resistance to Citrus Leprosis
}

\author{
Marinês Bastianel, Antonio Carlos de Oliveira, Mariângela Cristofani, Oliveiro Guerreiro Filho, Juliana Freitas-Astúa, \\ Vandeclei Rodrigues, Gustavo Astúa-Monge, and Marcos Antônio Machado
}

First, third, sixth, seventh, and eighth authors: Centro APTA Citros Sylvio Moreira/IAC, C.P. 04, Cordeirópolis, SP, 13490-970; second author: Depto. Ciências Naturais/UESB, C.P. 95, 45100-000, Vitória da Conquista, BA; fourth author: Centro APTA Café Alcides Carvalho/IAC, Campinas, SP; and fifth author: Centro Nacional de Pesquisa Milho e Sorgo/EMBRAPA, Sete Lagoas, MG, Brazil.

Accepted for publication 3 May 2006.

\begin{abstract}
Bastianel, M., de Oliveira, A. C., Cristofani, M., Filho, O. G., FreitasAstúa, J., Rodrigues, V., Astúa-Monge, G., and Machado, M. A. 2006. Inheritance and heritability of resistance to citrus leprosis. Phytopathology 96:1092-1096.

The genetic inheritance of resistance to leprosis, the most important viral disease of citrus in Brazil, was characterized through the phenotypic assessment of 143 hybrids resulting from crosses between tangor 'Murcott' (Citrus sinensis $\times$ C. reticulata) and sweet orange 'Pêra' (C. sinensis), considered to be resistant and susceptible to the disease, respectively. All plants were grafted onto Rangpur lime (C. limonia) and inoculated with Citrus leprosis virus, cytoplasmic type through the infestation with viruliferous mites, Brevipalpus phoenicis. The experiments were arranged in a completely randomized block design with 10 replicates.

Incidence and severity of the disease in leaves and stems as well as plant growth parameters (plant height and stem diameter) were recorded for 3 years after the infestation with the viruliferous mites. The average values of all variables were analyzed using principal component analysis, discriminant factorial analysis, estimation of the clonal repeatability coefficients, and frequency of the distributions of the average values for each measured variable. The principal component analysis resulted in the identification of at least two groups with resistance and susceptibility to leprosis, respectively. About $99 \%$ of all hybrids were correctly classified according to the discriminant factorial analysis. The broad-sense heritability coefficients for characteristics associated with incidence and severity of leprosis ranged from 0.88 to 0.96 . The data suggest that the inheritance of resistance to leprosis may be controlled by only a few genes.
\end{abstract}

Citrus leprosis, caused by Citrus leprosis virus (CiLV), is considered the most important viral disease affecting the crop in Brazil especially because of the elevated cost associated with controlling its vector, which can reach up to $\$ 75$ million per year (32).

The most common form of the virus is referred to as the cytoplasmic type (CiLV-C) due to its cellular localization and particular cytopathic effect (31). In contrast, a less frequent form of CiLV was first described in 1972 (CiLV-N) as being present in the nucleus of infected cells (17). The latter type is less prevalent and has been reported only in Panama (12) and in some regions of the States of São Paulo and Rio Grande do Sul, Brazil $(14,16)$.

Cytopathic effects similar to those observed with either the cytoplasmic or the nuclear types of CiLV have been described for other diseases exhibiting similar local lesions (chlorotic, green spots, or ring spots) in leaves, stems, and fruits of various hosts. In addition, these diseases, such as passion fruit green spot (18), coffee ring spot (5), and orchid fleck (19), are caused by virions of bacilliform shape and transmitted by Brevipalpus spp. (Acari: Tenuipalpidae).

Citrus leprosis is most easily identified because of its typical local lesion symptoms in all aerial parts of infected plants, the characteristic cytopathic effects observable by electron microscopy $(10,12,17,31)$, or the direct detection of its causal agent through reverse transcription-polymerase chain reaction (20).

Originally found in Florida in the beginning of the 20th century, in the last decades leprosis was restricted to some regions of South America (3). More recently, however, the disease was

Corresponding author: M. Bastianel

E-mail address: mbastianel@centrodecitricultura.br

DOI: 10.1094/PHYTO-96-1092

(C) 2006 The American Phytopathological Society reported in Costa Rica (1), Panama (12), Guatemala (21), and Bolivia (15). In addition, there are at least six other confirmed cases in the Americas. The reports of the presence of citrus leprosis in Central American countries have created a great concern within the U.S. citrus industry (8).

In Brazil, CiLV-C is transmitted in a persistent manner by the mite Brevipalpus phoenicis Geijskes, 1939 (22). The vector is polyphagous and can be found colonizing about 500 plant species widely distributed in tropical regions of the world (9). In Brazil, the management of $B$. phoenicis is based entirely on the use of acaricides since it seems to be the most efficient strategy for its control $(32,35)$.

Sweet oranges (Citrus sinensis Osb.) are the most susceptible citrus species to leprosis $(3,6,29-31)$. Even though several sources of resistance have been described among mandarins and their hybrids $(2,3,6,31)$, few studies have been conducted with the purpose of developing commercial varieties resistant to this disease. Generally speaking, some hybrids of mandarin with sweet orange such as tangor 'Murcott' exhibit high resistance to leprosis under field and greenhouse conditions $(2,29,30)$.

Despite the importance of leprosis for the citrus global production, very little is known about the heritability of resistance to CiLV-C in such host. As a result, a broad genetic breeding program has been developed by the Centro APTA Citros Sylvio Moreira/IAC, Cordeirópolis, São Paulo, Brazil, involving, among others, crosses between sweet orange 'Pêra' and tangor 'Murcott' with the purpose of developing resistant cultivars to leprosis and to other important diseases.

The main objective of the present work was to characterize the resistance to citrus leprosis in a hybrid population obtained from crosses between sweet orange 'Pêra IAC' and tangor 'Murcott'. The assessments focused on characters associated with resistance to the infection by CiLV-C when transmitted by the mite B. phoenicis, and to the development of symptoms under field conditions. 
The results presented here are based on the phenotypic segregation observed in our experiments and represent the first study of heritability of resistance to leprosis in citrus.

\section{MATERIALS AND METHODS}

Plant material and experimental design. One hundred fortythree hybrids obtained from crosses between sweet orange 'Pêra' (male) and tangor 'Murcott' were used for the assessments. The selection of zygotic hybrids and their vegetative propagation was carried out earlier as described by Oliveira et al. (23,24). All hybrids and the parental cultivars were grafted onto Rangpur lime.

The experimental design used was completely randomized blocks with 10 replications and a total of 1,450 plants. All experiments were conducted under the conditions of the Centro APTA Citros Sylvio Moreira/IAC, Cordeirópolis, Brazil.

Inoculation of the virus. A population of viruliferous B. phoenicis was reared in sweet orange fruits and transferred on average every 35 days to fresh fruits. For viral acquisition, the mite population was transferred and kept for $48 \mathrm{~h}$ on leaves of sweet orange 'Pêra' exhibiting initial symptoms of leprosis. This system has been proven to achieve up to $100 \%$ efficiency for the acquisition of the virus (2).

Inoculation of the hybrids and parental plants was carried out by transferring and attaching a symptomatic leaf of sweet orange carrying viruliferous mites to each of the plants (30 mites per plant) 6 months after grafting.

Phenotypic assessment. Twelve and thirty-six months after inoculation, incidence (percentage of leaves showing lesions) and severity of the disease in leaves and stems were recorded. In addition, the total number of mites in 20 leaves randomly sampled, the height of the plants, and the diameter of the trunk were also evaluated and recorded. Severity was measured using a descriptive scale, with scores from 0 (no lesions) to 5 ( $1=$ few lesions restricted to a particular region of the plant; $2=$ lesions in more than one plant tissue and/or distributed in more than one sector of the plant; $3=$ abundant lesions throughout the plant; $4=$ abundant lesions throughout the plant, and leaf and/or fruit drop; and $5=4$ plus branches dieback) (29). In addition, severity was assessed in a subset of 20 leaves per treatment through a diagrammatic scale including five levels of severity in leaves expressed as the percentage of infected area $(0.39,2,6,16.5$, and $39.5 \%$ ) (34). An additional assessment of severity was carried out 18 months after inoculation using only the descriptive scale.

Statistical analyses. The data related to the percentage of symptomatic leaves and the severity scores based on percentages (diagrammatic scale) were transformed using the arcsine of the square root of $x$ (36). Histograms of the distribution of variable frequencies, correlation analyses amongst variables, and the principal component analysis (PCA) were obtained using the software package Statistica version 6.0 (StatSoft Inc., Tulsa, OK). In order to compare the response of the two parental lines and the hybrid progeny to leprosis, PCA was carried out using the average values of all variables. A discriminant factorial analysis was also carried out in order to confirm the classification obtained by the PCA. Estimation of the clonal repeatability, a measure of broadsense heritability (13), was obtained using the Selegen-REML/ BLUP software package (Embrapa Florestas, Colombo, PR, Brazil), through model 20 (completely randomized blocks, unrelated clones, one parcel per block) $(27,28)$.

\section{RESULTS AND DISCUSSION}

Evaluations after 12 and 18 months of inoculation showed steady increase in disease incidence and severity over time (data not shown). Three years after the inoculations with viruliferous mites, no symptoms were observed in tangor 'Murcott' plants, while all plants of 'Pêra' exhibited typical symptoms of leprosis. Some sweet orange plants and hybrids died as a result of the disease. Even though plant death is not common in plants affected by leprosis, the high level of inoculum used in the experiments and the fact that all inoculated plants were relatively young contributed to the mortality observed in the field. The absence of symptoms in plants of tangor 'Murcott' and the high level of susceptibility observed in sweet orange plants confirmed previous reports on the differential response of these genotypes to leprosis $(2,4,30,33)$. Thus, the contrasting phenotypes observed in response to this disease made these parental lines suitable for crosses and the developing of a segregating population.

The frequency distributions of average values for all variables are shown in Figure 1. The variables associated with plant growth exhibited continuous, approximately normal distributions, while those related to leprosis resistance showed distinct classes in their distribution. The average values for the variables related to resistance in the parental lines remained in the borders of the histogram.

When all variables assessed in this work were compared, high correlation values $(P<0.05)$ were observed among all of them except for the number of mites per 20 sampled leaves. The incidence of the disease represented by the percentage of symptomatic leaves showed correlation values of 0.86 when compared with the severity data obtained in the assessments using the descriptive scale, and 0.87 when compared with the severity data obtained with the diagrammatic scale.

It should be noted that both descriptive and diagrammatic scales yielded similar results in the assessments, which suggests that either one of them could be used in further experiments involving this pathosystem. Despite the fact that diagrammatic scales are more widely used to assess disease severity, in this particular case the descriptive scale was as effective as the other one, since it took into consideration disease symptoms in branches as well.

In general, the high correlation values ( 0.86 and 0.87$)$ observed between incidence and severity indicate that the reaction to initial infection events may play an important role in the response of the tested genotypes to citrus leprosis. Thus, plants with higher percentage of symptomatic leaves showed a wider spread of the disease in leaves and stems (descriptive scale) and a larger area of symptomatic tissue in infected leaves (diagrammatic scale).

The number of mites per plant did not show any significant correlation with the other variables measured in this study. This lack of correlation could indicate that the plants do not exhibit any resistance response to mite infestation. The colonization by mites of tangor 'Murcott' has been reported before $(4,7,29)$. In fact, Childers et al. (7) described 496 plant species as potential hosts for B. phoenicis, including 15 species of Citrus, regardless of their susceptibility to CiLV. Therefore, these data support previous observations (29) indicating that different mechanisms of resistance to the virus and to mite colonization may be involved in the pathosystem leprosis.

PCA of the six variables evaluated in this work allowed the identification of at least two groups of plants, one susceptible (group I, at the left side of the $y$ axis) and one resistant (group II, at the right side of the $y$ axis) to the disease (Fig. 2). Group I includes those hybrids that presented average score higher than 1 when assessed through the descriptive scale. Hybrids were classified as members of group II if they remained asymptomatic or presented very few lesions in leaves only (average score lower than 1). Hence, hybrids with low incidence and severity of leprosis were not separated from the group of asymptomatic plants by PCA. A similar strategy was used to evaluate the witches'-broom disease in cocoa plants (26).

From the 143 evaluated hybrids, 87 were classified as resistant (R) and 56 as susceptible to leprosis $(\mathrm{S})$. The 15 genotypes that remained asymptomatic throughout the experiment are repre- 
sented by circles in Figure 2. A high homogeneity of the expression of resistance to leprosis was observed among plants in group II. In contrast, individuals in group I exhibited larger variation in their response to the disease. This heterogeneity among members of group I may indicate different degrees of susceptibility and, possibly, the presence of hybrids more susceptible to leprosis than the parental line sweet orange. This can be due to transgressive segregation, observed in both inter- or intra-specific crosses $(11,25,37)$.

Parental lines appeared well characterized in each group defined by the PCA. It is possible to observe small variations within each group in terms of vegetative growth indicating that there may be subgroups with differential vegetative vigor. However, although no correlation between vegetative vigor and resis-
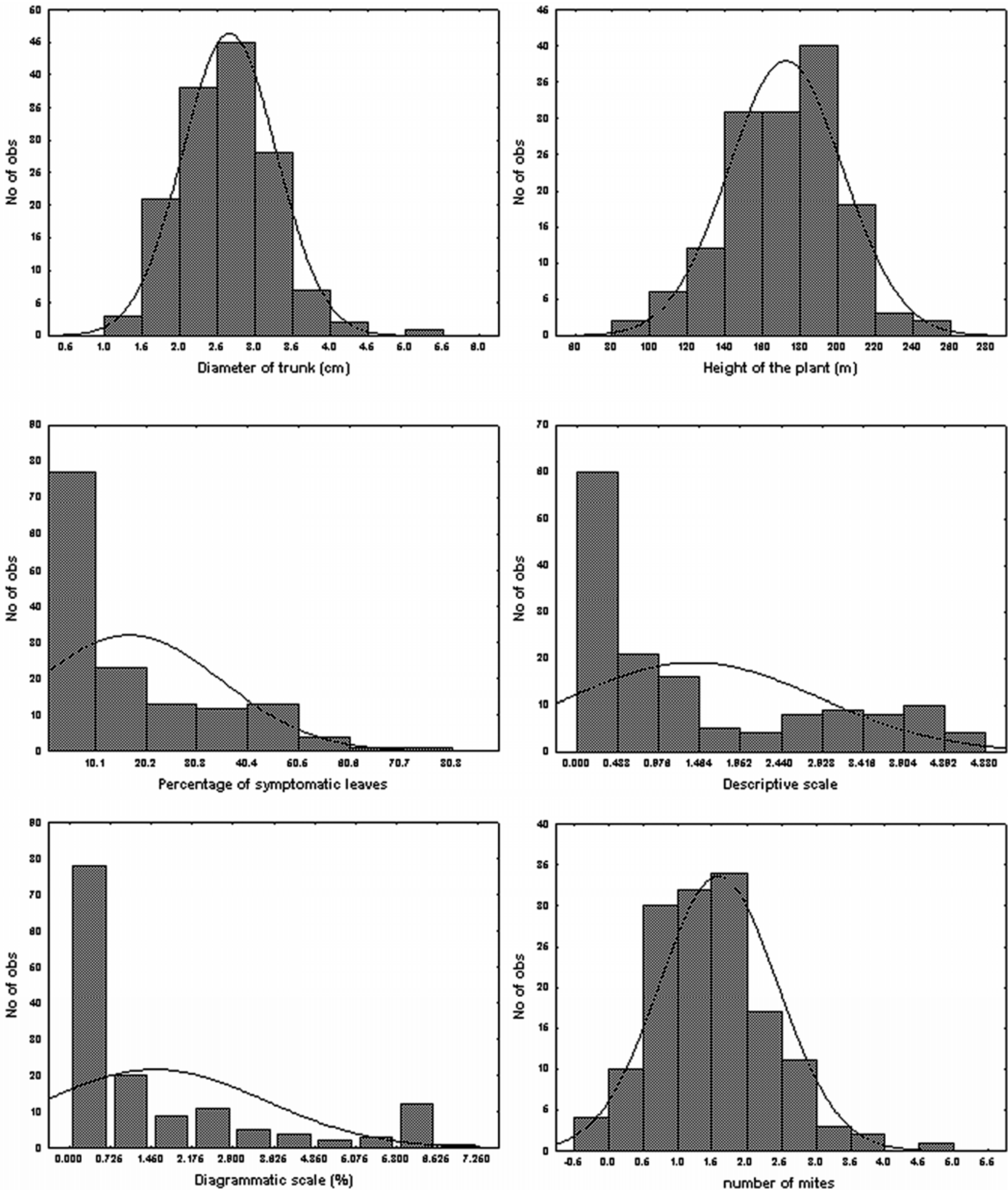

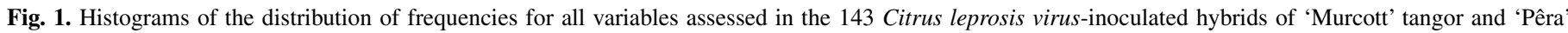
sweet orange. 
tance to leprosis was observed, the differential vegetative growth can be used, together with a measure of resistance, to select genotypes that combine vegetative vigor and resistance.

According to the PCA, $89.25 \%$ of the observed experimental variation is associated with at least two main factors (Fig. 2). Factor 1 explained $55.54 \%$ of the experimental variation and exhibited high correlation values with the data obtained with the descriptive scale $(91 \%)$, the percentage of symptomatic leaves $(95 \%)$, and the severity data obtained with the diagrammatic scale (87\%) (Fig. 2). Factor 2 explained $33.71 \%$ of the variation and showed high correlation values with plant height $(84 \%)$ and trunk diameter (90\%) (Fig. 2). The number of mites exhibited high correlation (99\%) with the third principal component, which explained less than $10 \%$ of the variability observed in the experiment. Therefore, this third component was not included in the PCA.

Incidence, descriptive, and diagrammatic measurements together showed high correlation with resistance to leprosis allowing the successful identification by PCA of resistant hybrids to CiLV-C when inoculated with viruliferous mites. These high correlation values allow choosing either the descriptive or diagrammatic scale for field assessments of resistance depending upon the ease of evaluation and the objectives of the experiment.

When the classification of individuals into two different groups, obtained by PCA, was validated by discriminant factorial analysis, $99 \%$ of the plants were considered well classified since they exhibited very specific characteristics to the groups each of them belonged to.
The clonal repeatability coefficients of resistance to leprosis after 3 years from inoculation were 0.96 when the severity values were obtained using the descriptive scale, 0.93 for the percentage of symptomatic leaves, and 0.88 for severity values obtained using the diagrammatic scale. Values close to those found for qualitative characters (13) suggest that environmental variance was well-controlled by the inoculation and replication procedures used in our study.

The frequency of segregation observed (87R:56S) did not correspond to a Mendelian segregation ratio; however, the fact that several distinct categories, both in the histograms and the PCA, and high clonal repeatability coefficients were observed strongly suggests that a major gene or few genes may be involved in controlling the inheritance of leprosis resistance.

\section{ACKNOWLEDGMENTS}

We thank N. Nogueira (CENA/USP) for providing the initial source of inoculum of CiLV-C, J. C. V. Rodrigues (Universidad de Puerto Rico) and R. Bassanezi (FUNDECITRUS) for their suggestion and help setting up the experiments; C. Nogueira and H. C. de Leão (Fischer S/A) for providing fresh fruits for maintaining the mite populations; Embrapa Florestas and M. D. V. Resende for providing the Selegen-REML/BLUP software; and A. A. F. Garcia (ESALQ/USP) and M. E. Zagatto Paterniani (IAC) for their valuable discussions on genetics. This work was partially funded by $\mathrm{CNPq}$ (Millennium Institute), FAPESP (Proc. 04/10511-3) and it is part of the doctoral dissertation of the first author (FAPESP, Proc. 01/8181-7).

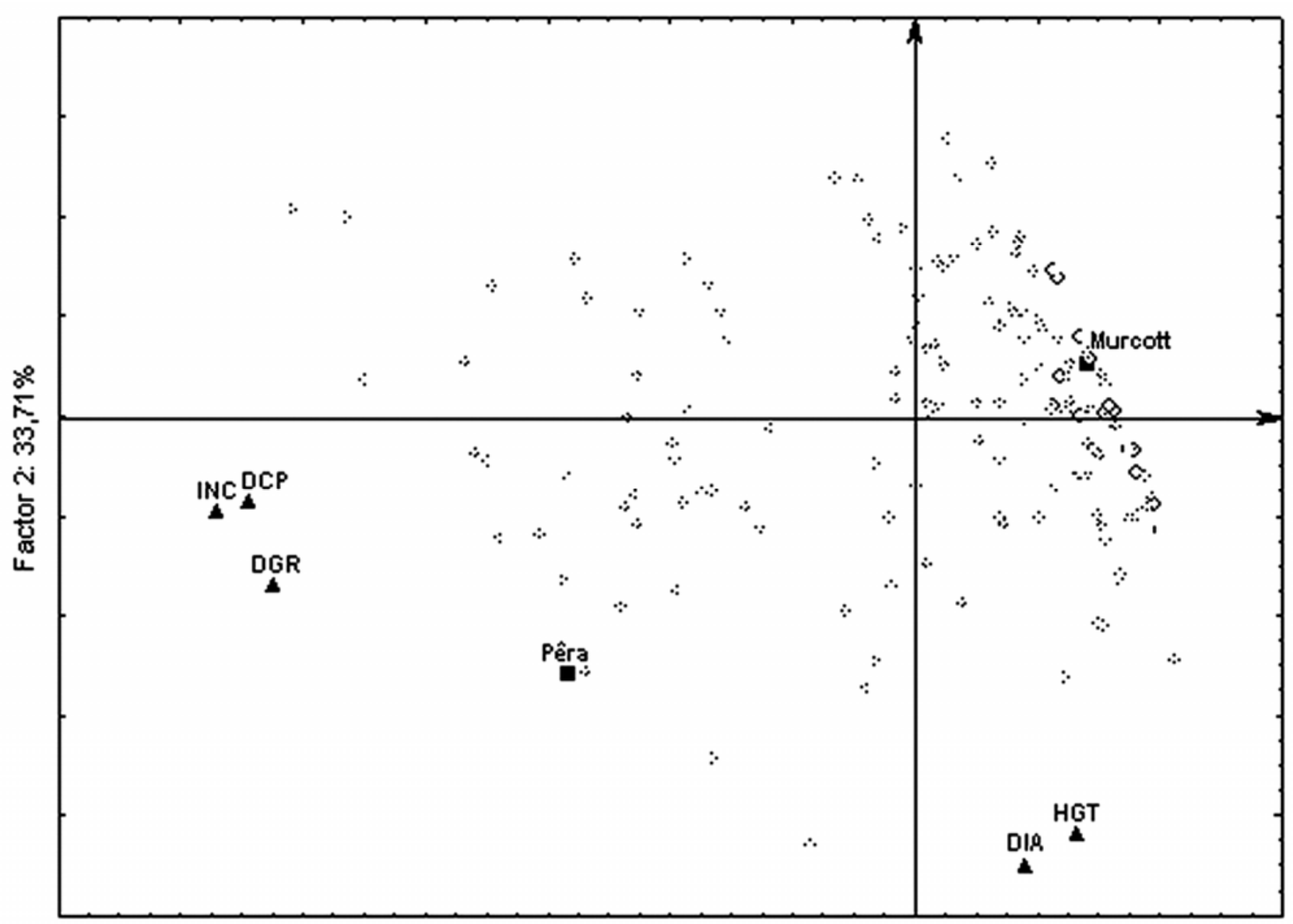

Factor 1: $55,54 \%$

Fig. 2. Dispersion diagram from principal components analysis and classification of the reaction of 143 hybrids obtained from the cross between 'Murcott' tangor and 'Pêra' sweet orange to the inoculation of Citrus leprosis virus, cytoplasmic type, with viruliferous mites. Triangles represent projection of the variables related to infection (INC = percentage of symptomatic leaves, DGR = severity data obtained using diagrammatic scale, and DCP = severity data obtained using descriptive scale) and vigor of infected plants (HGT = height of the plants and DIA = diameter of trunk), on the plane 1-2. Circles represent the 15 genotypes that remained asymptomatic throughout the experiment. 


\section{LITERATURE CITED}

1. Araya Gonzáles, J. 2000. Informe sobre la prospección de la "leprosis de los cítricos" en la zona fronteriza sur (Costa Rica - Panamá). Ministério de Agricultura y Ganadería.

2. Bastianel, M., Freitas-Astua, J., Rodrigues, V., Arrivabem, F., AntonioliLuizon, R., and Machado, M. A. 2004. Resposta do tangor 'Murcott' à inoculação do vírus da leprose dos citros a campo e em casa de vegetação. Laranja 25:337-348.

3. Bitancourt, A. A. 1955. Estudos sobre a leprose dos citros. Arq. Inst. Biol. 22:161-203.

4. Boaretto, M. A. C., and Chiavegato, L. G. 1994. Transmissão da leprose por ácaros Brevipalpus phoenicis (GEIJSKES, 1939) (Acari: Tenuipalpidae) temporariamente mantidos em hospedeiros intermediários, em condições de laboratório. Científica 22:81-93.

5. Chagas, C. M., Kitajima, E. W., and Rodrigues, J. C. V. 2003. Coffee ringspot virus vectored by Brevipalpus phoenicis (Acari: Tenuipalpidae) in coffee. Exp. Appl. Acarol. 30:181-203.

6. Chiavegato, L. G., and Mischan, M. M. 1987. Comportamento do ácaro Brevipalpus phoenicis (Geijskes, 1939) (Acari: Tenuipalpidae) em frutos de diferentes variedades cítricas. Científica 15:17-22.

7. Childers, C. C., French, J. V., and Rodrigues, J. C. V. 2003. Brevipalpus californicus, B. obovatus, B. phoenicis, and B. lewisi (Acari: Tenuipalpidae): A review of their biology, feeding injury and economic importance. Exp. Appl. Acarol. 30:5-28.

8. Childers, C. C., Rodrigues, J. C. V., Derrick, K. S., Achor, D. S., French, J. V., Welbourn, W. C., Ochoa, R., and Kitajima, E. W. 2003. Citrus leprosis and its status in Florida and Texas: Past and present. Exp. Appl. Acarol. 30:181-202.

9. Childers, C. C., Rodrigues, J. C. V., and Welbourn, W. C. 2003. Host plants of Brevipalpus californicus, B. obovatus, and B. phoenicis (Acari: Tenuipalpidae) and their potential involvement in the spread of one or more viral diseases vectored by these mites. Exp. Appl. Acarol. 30:29105.

10. Colariccio, A., Lovisolo, O., Chagas, C. M., Galetti, S. R., Rossetti, V., and Kitajima, E. W. 1995. Mechanical transmission and ultrastructural aspects of citrus leprosis virus. Fitopatol. Brasil. 20:208-213.

11. De Vicente, M. C., and Tanksley, S. D. 1993. QTL analysis of transgressive segregation in an interspecific tomato cross. Genetics 116:585-596.

12. Dominguez, F. S., Bernal, A., Childers, C. C., and Kitajima, E. W. 2001. First report of citrus leprosis in Panama. Plant Dis. 85:228.

13. Falconer, D. S. 1989. Introduction to Quantitative Genetics. Longman Scientific and Technical, Stanford, NY.

14. Freitas-Astua, J., Kitajima, E. W., Bastianel, M., Locali, E. C., Antonioli, R., and Machado, M. A. 2004. Identification of citrus leprosis vírusnuclear type (CiLV-N) in sweet orange in the state of Rio Grande do Sul. (Abstr.) Virus Rev. Res. 9 (suppl.1):247.

15. Gómez, C., Vargas, M. R., Rivadameira, C., Locali, E. C., Freitas-Astúa, J., Astua-Monge, G., Rodrigues, J. C. V., Mesa Cobo, N. C., and Kitajima, E. W. 2005. First report of citrus leprosis vírus on citrus in Santa Cruz, Bolívia. Plant Dis. 89:686.

16. Kitajima, E. W., Ferreira, P. T. O., Freitas-Astua, J., and Machado, M. A. 2004. Ocorrência da leprose dos citros, tipo nuclear (CiLV-N) nos municípios paulistas de Monte Alegre do Sul e Amparo. (Abstr.) Summa Phytopathol. 30:68.

17. Kitajima, E. W., Müller, G. W., Costa, A. S., and Yuki, W. 1972. Short, rodlike particles associated with citrus leprosis. Virology 50:254-258.

18. Kitajima, E. W., Rezende, J. A. M., and Rodrigues, J. C. V. 2003. Passion fruit green spot virus vectored by Brevipalpus phoenicis (Acari: Tenuipalpidae) in passion fruit in Brazil. Exp. Appl. Acarol. 30:225-231.
19. Kondo, H., Maeda, T., and Tamada, T. 2003. Orchid fleck virus: Brevipalpus californicus mite transmission, biological properties and genome structure. Exp. Appl. Acarol. 30:215-223.

20. Locali, E. C., Freitas-Astúa, J., Souza, A. A., Takita, M. A., Astúa-Monge, G., Antonioli, R., Kitajima, E. W., and Machado, M. A. 2003. Development of a molecular tool for the diagnosis of leprosis, a major threat to Citrus production in the Americas. Plant Dis. 87:1317-1321.

21. Mejia, L., Paniagua, A., Cruz, N., Porras, M., and Palmieri, M. 2002. Citrus leprosis, disease that endangers plantations in Guatemala. Page 69 in: Proc. 42nd Annual Meeting of The American Phytopathological Society, Caribbean Division.

22. Mussumeci, M. R., and Rosseti, V. 1963. Transmissão dos sintomas da leprose dos citros pelo acaro Brevipalpus phoenicis. Ciência Cultura $15: 228$.

23. Oliveira, A. C., Novelli, V. M., Garcia, A. N., Cristofani, M., and Machado, M. A. 2000. Identification of sexual and nucellar Citrus seedlings through single and duplex PCR of simple sequence repeat Locus. Proc. Intl. Soc. Citriculture I:138-141.

24. Oliveira, A. C., Novelli, V. M., Garcia, A. N., Cristofani, M., and Machado, M. A. 2002. Identification of citrus hybrids through the combination of a leaf apex morphology and SSR markers. Euphytica 128:397403.

25. Paterson, A. H. L., Lander, E., Lincoln, S., Hewitt, J., Peterson, S., and Tanksley, S. 1988. Resolution of quantitative traits into Mendelian factors by using a complete linkage map of restriction fragment length polymorphism. Nature 335:721-726.

26. Queiróz, V. T., Guimarães, C. T., Anhert, D., Scguster, I., Daher, R. T., Pereira, M. G., Miranda, V. R. M., Loguercio, L. L., Barros, E. G., and Moreira, M. A. 2003. Identification of a major QTL in cocoa (Theobroma cacao L.) associated with resistance to witches' broom disease. Plant Breed. 122:268-272.

27. Resende, M. D. V. 2000. Análise estatística de modelos mistos via REML/BLUP na experimentação em melhoramento de plantas perenes. Embrapa Florestas, Colombo. (documentos 47).

28. Resende, M. D. V. 2002. Genética Biométrica e Estatística no Melhoramento de Plantas Perenes. Embrapa Informação Tecnológica, Brasília.

29. Rodrigues, J. C. V. 2000. Relações patógeno-vetor-planta no sistema leprose dos citros. 2000. Tese (Doutorado em Ciências, Área de Concentração em Energia Nuclear na Agricultura)-Centro de Energia Nuclear na Agricultura, Universidade de São Paulo, Piracicaba.

30. Rodrigues, J. C. V., Fioravante, A. M., and Nogueira, N. L. 1995. Leprose dos citros: Variabilidade de Citrus spp. ao patossistema ácaro-patógeno. (Abstr.) Fitopatol. Brasil. 20:309-310.

31. Rodrigues, J. C. V., Kitajima, E. W., Childers, C. C., and Chagas, C. M. 2003. Citrus leprosis virus vectored by Brevipalpus phoenicis (Acari: Tenuipalpidae) on citrus in Brazil. Exp. Appl. Acarol. 30:161-179.

32. Rodrigues, J. C. V., and Machado, M. A. 2000. Virus-Brevipalpus-plant relationships of the citrus leprosis pathosystem. Proc. Intl. Soc. Citriculture IX:768-770.

33. Rodrigues, J. C. V., Muller, G. W., Nogueira, N. L., and Machado, M. A. 2000. Yield damage associated to citrus leprosis on sweet-orange varieties. Proc. Intl. Soc. Citriculture IX:1055-1059.

34. Rodrigues, J. C. V., Nogueira, N. L., and Machado, M. A. 2002. Elaboração e validação de escala diagramática para leprose dos citros. Summa Phytopathol. 28:192-196.

35. Salvo Filho, A. 1997. Notas sobre o tratamento fitossanitário em citros. Laranja 18:155-163.

36. Steel, R. G. D., and Torrie, J. H. 1980. Principles and Procedures of Statistics. McGraw-Hill, Tokyo.

37. Tanksley, S. D. 1993. Mapping polygenes. Annu. Rev. Genet. 27:205-233. 